\title{
ANALISIS SISTEM DINAMIK NERACA AIR DI PULAU TIDORE
}

\author{
Oleh : \\ Halima Malaka, Dr. Ir. M.Yanuar J. Purwanto,MS, dan Dr. Ir. Alinda Zein, M.Si \\ Institut Pertanian Bogor
}

Pusat Teknologi Lingkungan, BPPT

Jl. M.H. Thamrin No. 8 Gd. II Lt. 18 Jakarta 10340

\begin{abstract}
Abstrak
Penelitian ini dilakukan di Pulau Tidore Kota Tidore Kepulauan Propinsi Maluku Utara. Tujuan dari penelitian ini adalah 1) membangun model neraca air di Pulau Tidore. Metode yang digunakan pada penelitian adalah metode survei dengan melakukan analisis neraca air. Analisis data yang digunakan adalah analisis sistem dinamik untuk mengetahui neraca dari tahun 2009 2032 dengan sofware stella versi 9.0.2. Hasil analisis menunjukkan bahwa pada 2009 nerca air 21,189,941.20 m3 / tahun dan pada 2032 terjadi defisit 427,678.61 m3 / tahun. Indeks ketersediaan air (IKA) pada tahun 2009 sebesar 1.416,10 dan pada tahun 2032 sebesar 82,54 IKA nilai, ini menunjukkan bahwa pada 2032 ketersediaan air tanah hanya mampu melayani 82,54\% kebutuhan air .Untuk meningkatkan neraca air perlu dilakukan kebijakan hemat air dan konservasi pada masing penggunaan lahan.Upaya penghematan penggunaan air dan konservasi air tanah dilakukan dengan menggunakan 3 skenario kebijakan, dari hasil simulasi model diperoleh bahwa skenario 2 yakni penghematan penggunaan air dapat menaikan neraca air pada tahun 2009 menjadi 21,270,444.14 m3 / tahun dengan nilai IKA 1490.63 dan pada tahun 2032 defisit air sebesar 31.128,46 $\mathrm{m}^{3}$ /tahun. Sedangkan hasil simulasi skenario 3 yakni skenario terpadu antara penghematan penggunaan air dan konservasi dapat menaikan neraca air pada tahun 2009 sebesar 21,350,947.08 $\mathrm{m}^{3}$ /tahun dan IKAsebesar 1.573,44 dan pada tahun 2032 nilai IKA menjadi 117,92 menunjukkan ketersediaan air tanah mampu melayani 117,92\% dari kebutuhan air
\end{abstract}

Kata kunci : Ketersediaan air tanah, kebutuhan air, sistem dinamik, neraca air

\begin{abstract}
This research was conducted at Tidore Island, -Tidore City, North Maluku Archipelago Province. Objective of this study were 1) build a water balance model Tidore Island. This Method used in this research is method of survey with water balance analysis. Analysis of the data used is the analysis of dynamic system to determine the balance of the year 2009 - 2032 with software stella version 9.0.2. The result of analysis showed that in 2009 there were water balance 21,189,941.20 $\mathrm{m3}$ / year and in 2032 there was a deficit of 427,678.61 m3 / year. Water availability index (IKA) in 2009 amounted to 1416.10 and in the year 2032 amounted to 82.54 IKA the value, it indicates that in 2032 the availability of groundwater only able to serve $82.54 \%$ the water demand. To improve the balance of water needed for water saving and conservation policies at each land use.Saving measures water use and conservation of groundwater done using three policy scenarios, the model simulation results indicate that both scenarios can increase the efficiency of water use and water balance in 2009 to 21,270,444.14 m3 / year with a value of 1490.63 and value IKA in 2032 can be water deficit of $31128.46 \mathrm{m3} /$ year. While the results of the simulation scenario 3 scenario between saving integrated water use and conservation can improve the water balance in 2009 amounted to 21,350,947.08 m3 / year and the value IKA 1573.44, and in 2032 the value decreased to 117.92 IKA shows the availability of ground water able to serve $117.92 \%$ of water demand people.
\end{abstract}

Keywords: water balance,system dynamic, water demand, ground water availability 


\section{PENDAHULUAN}

\subsection{Latar Belakang}

Air merupakan unsur utama bagi mahluk hidup di bumi. Air merupakan elemen yang melimpah dibumi, yang meliputi $70 \%$, namun hanya sebagian kecil saja yang benar-benar dimanfaatkan, yaitu 0,003 \% dan $97 \%$ adalah laut. Sedangkan 3 \% sisanya yang ada hampir semuanya atau kira-kira $87 \%$ tersimpan dalam kutub atau sangat dalam dibawah tanah ${ }^{1)}$. Dalam mempelajari serta mengevaluasi sumberdaya air di suatu daerah, segi kuantitas dan kualitas harus diketahui karena kedua hal tersebut merupakan ukuran yang harus dipertimbangkan dalam pemanfaatan sumberdaya air.

Luas daratan Pulau Tidore sebesar 116,56 $\mathrm{Km}^{2}$, luas tersebut menyebabkan Pulau Tidore termasuk kategori pulau kecil karena memiliki luasan $<2000 \mathrm{~km}^{2}$ (PP No 62 tahun 2010). Konsekuensi sebagai pulau gunungapi dan pulau kecil maka Pulau Tidore memiliki berbagai keterbatasan wilayah salah satunya adalah daerah tangkapan hujan yang terbatas, rata-rata curah hujan tahunan 2058,2 $\mathrm{mm} /$ tahun, suhu rata-rata bulanan $26,7^{\circ} \mathrm{C}$.

Pulau Tidore merupakan ibu kota dari kota Tidore Kepulauan secara Pulau Tidore sebagai pusat pemerintahan terus memacu pembangunan dan pertumbuhan ekonomi sehingga memacu pertumbuhan penduduk, pertumbuhan dunia usaha, pembangunan fasilitas umum dan fasilitas komersil yang berdampak pada peningkatan kebutuhan air bersih. Sebagai pulau kecil ketersediaan air tanah pun terbatas oleh karena itu untuk mengetahui ketersediaan air di pulau Tidore apakah surplus atau defisit maka perlu menganalisis neraca air dengan pendekatan sistem diamik.

\subsection{Tujuan}

Penelitian ini bertujuan untuk :

a. Membangun model neraca air untuk mengelolah air tanah di Pulau kecil

b. Aplikasi model dinamik dengan menerapkan skenario konservasi dalam rangka mengetahui neraca air pada tahun 2032 sesuai dengan RTRW Kota Tidore Kepulauan

\section{METODOLOGI}

\subsection{Lokasi dan Waktu Penelitian}

Penelitian ini akan dilaksanakan di Pulau Tidore Kota Tidore Kepulauan Propinsi Maluku Utara. Wilayah penelitian meliputi 4 wilayah kecamatan yang terdapat di Pulau Tidore yakni Kecamatan Tidore, Kecamatan Tidore Utara, Kecamatan Tidore
Selatan dan Kecamatan Tidore Timur, Lokasi penelitian (Gambar 1)

\subsection{Metode Analisis Data}

\subsubsection{Analisa sistem dinamik}

Metode analisis data yang digunakan dalam analisis sistem dinamik neraca air di Pulau Tidore yaitu dengan menggunakan Stella versi 9.0.2. Tahapan pendekatan sistem mencakup : analisis kebutuhan, formulasi masalah, identifikasi sistem, pemodelan sistem dan validasi model ${ }^{2)}$.

Uji validasi model terdiri dari dua bentuk uji yaitu uji validasi struktur dan uji validasi kinerja.

\section{a. Uji validasi struktur}

Uji ini lebih menekankan apakah struktur yang di bangun mendekati struktur nyata. Kemiripan struktur model dengan struktur nyata ditujukan dengan sejauhmana interaksi variabel model dapat menirukan interaksi kejadian nyata.

b. Uji validasi kinerja

Uji validasi kinerja dalam penelitian ini menggunakan uji validasi AME (Absolute Means Error) dan AVE (Absolute Variance Error) dengan menggunakan data jumlah penduduk dan jumlah fasilitas umum, persamaan matematikanya adalah ${ }^{3)}$ :

$$
\begin{array}{ll}
A M E=\frac{\bar{S}-\bar{A}}{\bar{A}} \times 100 \% ; & \bar{S}=\frac{\sum S i}{N} ; \quad \bar{A}=\frac{\sum A i}{N} \\
A V E=\frac{S S-S a}{S a} \times 100 \% ; & S S=\frac{\sum(S i-\bar{S})^{2}}{N} ; \quad S a=\frac{\sum(A i}{N}
\end{array}
$$

Keterangan :

S : Nilai simulasi,

A : Nilai aktual dan

$\mathrm{N}$ : Nilai interval waktu pengamatan.

Ss : Nilai standar deviasi simulasi

Sa : Nilai standar deviasi aktual.

Batas penyimpangan yang dapat di terima adalah maksimal $10 \%$.

\section{HASIL DAN PEMBAHASAN}

\subsection{Model Neraca Air}

Model dinamik neraca air dianalisis dengan Stella versi 9.0.2. Simulasi model dilakukan untuk pulau kecil. Analisis dilakukan selama 23 Tahun, yang dimulai dari tahun 2009 dan berakhir ahun 2032. Dalam kurun waktu tesebut diharapkan dapat memberikan gambaran perkembangan neraca air di Pulau Tidore 
Indentifikasi sistem dimaksudkan untuk memberikan gambaran tentang hubungan antara faktor-faktor yang saling mempengaruhi dalam pembentukan suatu sistem digambarkan dalam bentuk diagram sebab akibat (causal loop) kemudian di interpretasikan dalam konsep diagram input output (kotak hitam) sebagaimana Gambar (2).

\subsection{Validasi model neraca air}

Keobyektifan model ditujukan dengan sejauhmana model dapat menirukan fakta atau data empiris. Validasi merupakan salah suatu kriteria penilaian keobyektifan dari pemodelan dengan pendekatan sistem dinamik. Teknik validasi yang utama dalam metode berfikir sistem adalah validasi struktur model dan validasi kinerja.

\subsubsection{Uji validasi struktur}

Terdapat dua jenis validasi struktur yakni validasi kontruksi daji validasi kestabilan struktur. Validasi kontruksi yaitu keyakinan terhadap kontruksi model valid secara ilmiah, dan validasi kestabilan struktur yaitu kekuatan struktur dalm dimensi waktu. Tujuan dari uji validasi struktur adalah untuk memperoleh keyakinan sejauhmana kemiripan struktur model mendekati struktur nyata ${ }^{4)}$.

Bedasarkan Gambar 5 neraca air mengalami defisit seiring meningkatnya kebutuhan air. Berdasarkan simulasi model terlihat bahwa apa yang terjadi dalam dunia model memiliki kemiripan dengan dunia nyata karena secara logika bila kebutuhan air meningkat maka ketersediaan air menurun, oleh karena itu dapat disimpulkan bahwa model ini dapat dikatakan valid.

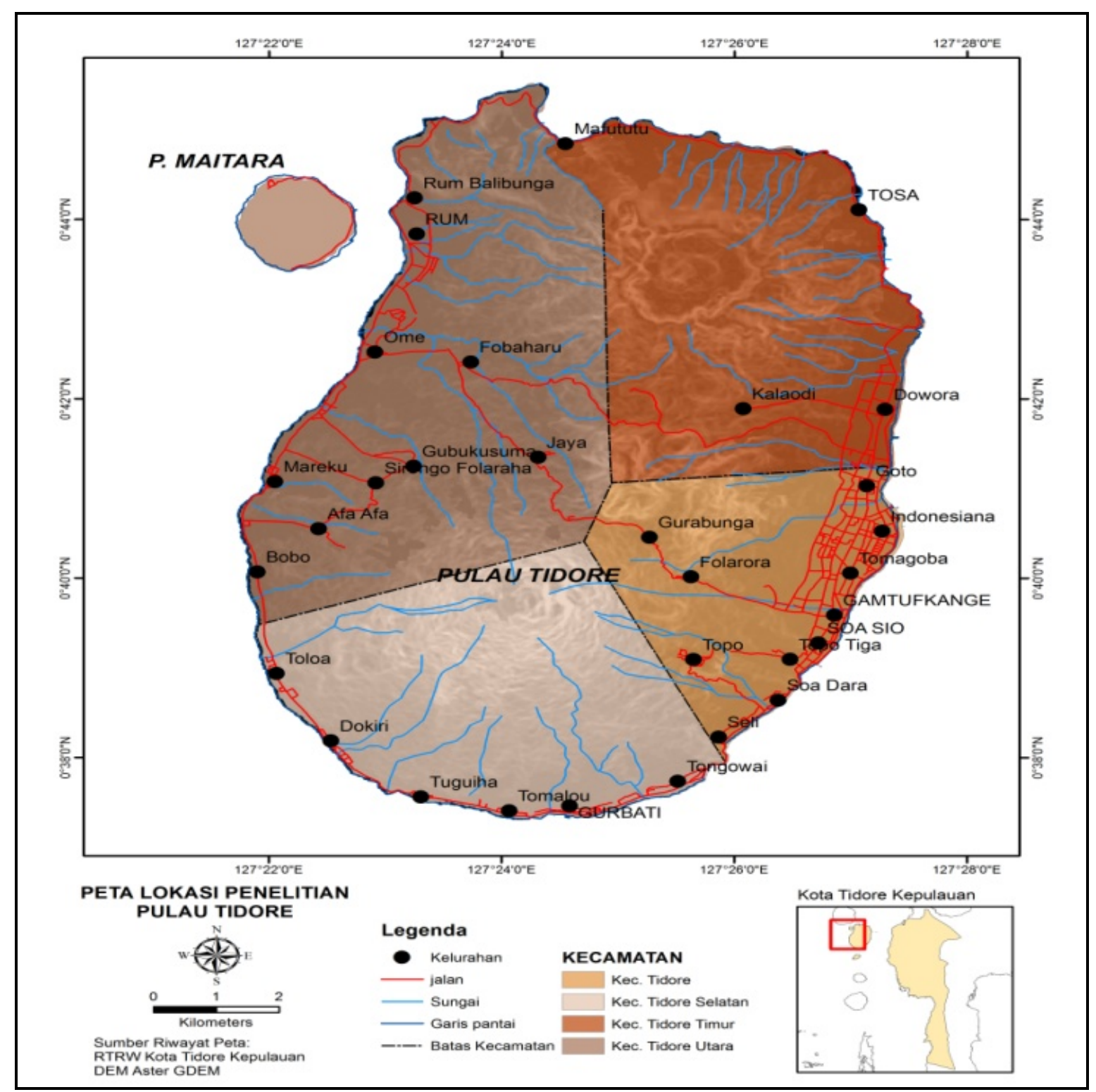

Gambar 1 : Lokasi penelitian 


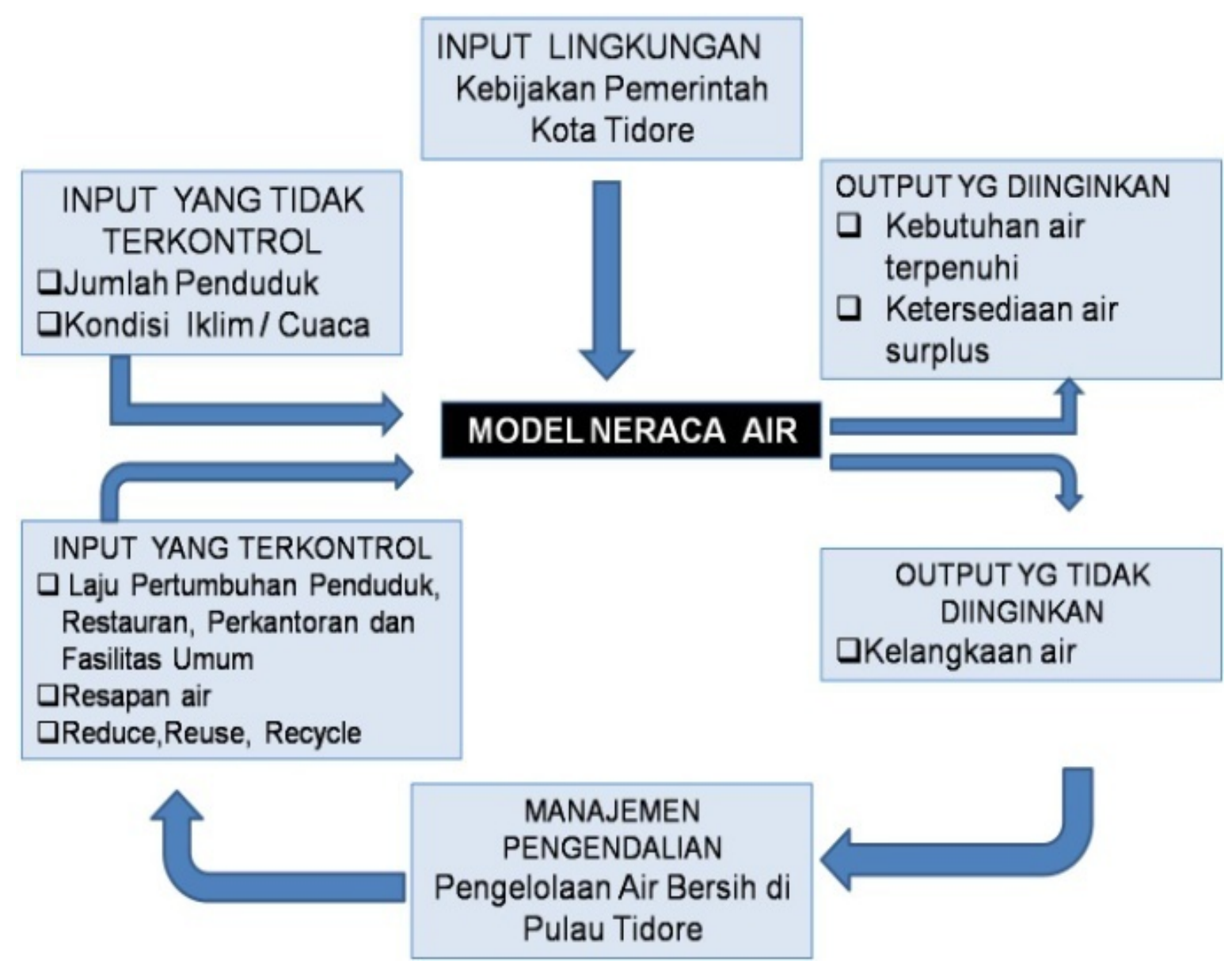

Gambar 2 : Diagram input output model neraca air tanah di Pulau Tidore

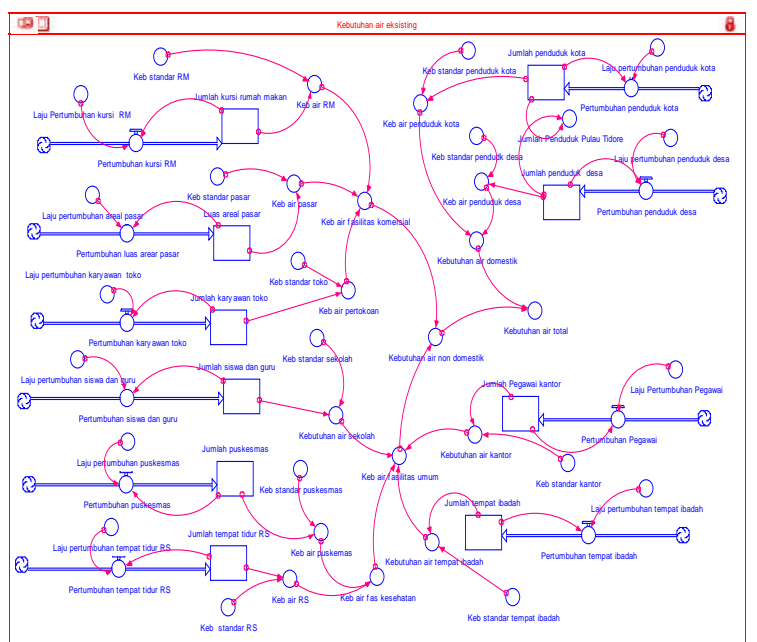

Gambar 3 : Struktur model kebutuhan air

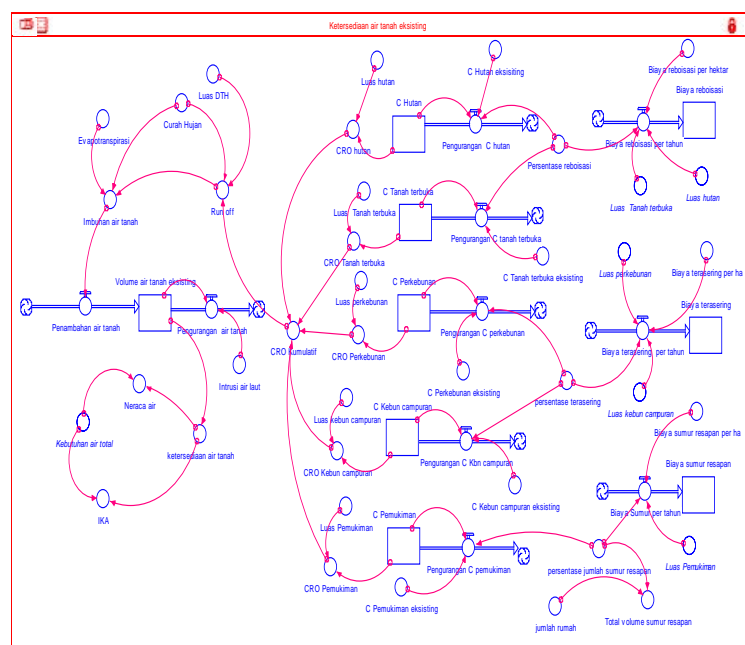

Gambar 4 : Struktur model ketersediaan air tanah 


\subsubsection{Uji validasi kinerja}

Validsi kinerja adalah aspek pelengkap dalam metode berpikir sistem. Tujuannya adalah untuk memperoleh keyakinan sejauhmana kinerju. model sesuai dengan kinerja sistem nyata sehingga memenuhi syarat sebagai model ilmiah yang taat fakta. Uji validasi kinerja dilakukan dengan cara memvalidasi kinerja model dengan data empiris, untuk melihat sejauh mana perilaku output model sesuai dengan perilaku data empirik. Uji validasi ini dilakukan dengan menggunakan uji statistik untuk melihat penyimpangan output simulasi terhadap data aktual melalui nilai absolut varian error (AVE) dan absolut mean error (AME). Nilai tersebut mempunyai dengan batas penyimpangan yang dapat diterima maksimal $10 \%$.

Untuk melakukan validasi kinerja dapat menggunakan satu atau beberapa variabel. Uji validasi kinerja yang dilakukan dalam penelitian ini adalah uji validasi kinerja dan absolut mean error (AME) dan absolut varian error (AVE) dengan menggunakan variabel jumlah penduduk dari tahun 2009 sampai tahun 2013. Hasil perhitungan uji validasi kinerja dapat diliht pada Tabel 1.

Dari hasil perhitungan uji validasi kinerja pada model neraca air di peroleh nilai AME 0,032 \% dan AVE 0,51 \%, sehingga dapat disimpulkan bahwa model ini memiliki kinerja yang baik, relatif tepat dan dapat diterima secara ilmiah.

Tabel 1 : Validasi kinerja model neraca air

\begin{tabular}{|l|c|c|c|}
\hline \multirow{2}{*}{ Keterangan } & Tahun & \multicolumn{2}{|c|}{ Data } \\
\cline { 3 - 4 } & & Simulasi & Aktual \\
\hline \multirow{4}{*}{ Neraca air } & 2009 & 21.189 .941 & 21.199 .374 \\
(m/Tahun) & 2010 & 18.881 .643 & 19.579 .548 \\
& 2011 & 18.468 .089 & 17.940 .314 \\
& 2012 & 14.924 .532 & 16.281 .278 \\
& 2013 & 13.232 .335 & 14.601 .302 \\
& MEAN & 17.339 .308 & 17.920 .363 \\
& VAR & 10.294 .672 .348 .907 & 6.801 .992 .978 .945 \\
& AME & 0,0324 & \\
& AVE & 0,51 & \\
\hline
\end{tabular}

\subsection{Simulasi Model Neraca Air}

\subsubsection{Kondisi eksisting Pulau Tidore}

Pulau Tidore mempunyai daerah tangkapan hujan yang terbatas sedangkan pertumbuhan penduduk setiap tahun meningkat menyebabkan kebutuhan air terus meningkat hal ini berdampak pada ketersediaan air tanah yang menurun. Disamping itu belum ada upaya penghematan pemakaian air. Simulasi model dilakukan selama 23 tahun yaitu dari tahun 2009 - 2032 (Gambar 6) dengan menggunakan data kondisi eksisting Pulau Tidore mencakup :

a. Pulau Tidore memiliki luas daerah tangkapan hujan P.Tidore 11.656 ha , luas wilayah 117,02 $\mathrm{km}^{2}$ atau 11.760,2 ha terbagi atas 5 land use yaitu pemukiman seluas 2885,49 ha, kebun campuran seluas 5910,43 ha, perkebunan seluas 177,87 ha, hutan seluas 2647,24 ha, tanah terbuka seluas 34,97 ha. Volume air tanah eksisting $114.000 .000 \mathrm{~m}^{3} /$ tahun digunakan untuk memenuhi kebutuhan air penduduk dan non penduduk.

b. Jumlah penduduk tahun 2009 sebesar 51848 jiwa, jumlah yang berdomisili di desa sebesar 39126 jiwa dengan laju pertumbuhan penduduk rata-rata $1,5 \%$ dan 12.722 jiwa berdomesili di kota dengan laju pertumbuhan $2 \%{ }^{5}$

c. Kebutuhan air penduduk tahun 2009 1.414.083 $\mathrm{m}^{3} /$ tahun, Kebutuhan air non penduduk $190.884,05 \mathrm{~m}^{3} /$ tahun, kebutuhan air bersih total $1.604 .967,05 \mathrm{~m}^{3} /$ tahun

d. Koefisien run-off eksisting lahan pemukiman 0,5, kebun campuran 0,15, Perkebunan 0,15, hutan 0,1 dan tanah terbuka 0,4.

e. Curah hujan rata-rata tahunan P.Tidore adalah $2058 \mathrm{~mm} /$ tahun, evapotranspirasi 735.8 $\mathrm{mm} /$ tahun, limpasan aliran permukaan 1455 $\mathrm{mm} /$ tahun.

Dari Tabel 2 menunjukan bahwa pada kondisi eksisting neraca air bersih menunjukkan ketersediaan air surplus sampai tahun 2030 dan terjadi defisit dari tahun 2031 - 2032. Nilai IKA menunjukan bahwa untuk kondisi eksisiting terus mengalami penurunan seiring dengan meningkatnya kebutuhan air bersih. Hasil simulasi nilai IKA di akhir tahun simulasi yakni sebesar $82,54 \%$, ini menunjukan bahwa pada kondisi eksisting ketersediaan air bersih hanya mampu melayani 82,54 $\%$ kebutuhan air bersih.

\subsubsection{Simulasi skenario kebijakan}

Beberapa skenario yang dapat didesain berdasarkan beberapa kebijakan yang dibuat untuk meningkatkan neraca air di Pulau Tidore yaitu :

\section{a. Skenario1 (Bussines As Usualy) \\ Skenario 1 (Bussines As Usualy)} menggambarkan kondisi yang terjadi saat ini tanpa ada usaha untuk pencegahan yang didesain dari kondisi variabel penentu kinerja sistem yang memberikan dampak yang tidak diinginkan.

Laju pertumbuhan penduduk yang terus meningkat tanpa ada upaya untuk menekan pertumbuhan penduduk, begitu juga dengan fasilitas umum dan fasilias komersil. Koefisien run off berada 
pada kondisi maksimum sehingga limpasan aliran permukaan sangat tinggi karena belum adanya upaya konservasi air tanah melalui program reboisasi, terasering dan sumur resapan. Hasil simulasi skenario 1 sama dengan kondisi eksisting (Gambar 7).

\section{b. Skenario reduce dan reuse}

Skenario reduce dan reuse didesain berdasarkan kondisi terjadinya penurunan laju pertumbuhan penduduk, pertumbuhan fasilitas umum dan fasilitas komersil. Adanya kebijakan hemat air (reduce dan reuse) sebesar $5 \%$ dalam pemakaian air tanah oleh penduduk, fasilitas umum dan fasilitas komersil akan meningkatkan volume air tanah eksisting .

Hasil simulasi skenario 2 terlihat bahwa pada tahun 2032 kebutuhan air meningkat sebesar 2.052.422,67 $\mathrm{m}^{3} /$ tahun sehingga ketersediaan air tanah menurun menjadi $2.021 .924,21 \mathrm{~m}^{3} /$ tahun menurunnya ketersediaan air tanah selain di pengaruhi oleh kebutuhan air yan meningkat juga dipengaruhi pengurangan akibat intrusi air laut. Neraca air skenario 2 pada tahun 2009 sebesar 21.270.444,14 $\mathrm{m}^{3} /$ tahun dan pada tahun 2032 terjadi defisit sebesar $31.428,46 \mathrm{~m}^{3}$ /tahun. Nilai indeks ketersediaan air (IKA) pada tahun 2009 sebesar 1490,23\% dan pada tahun 2032 nilai IKA 98,48 ini memunjukan bahwa pada tahun 2032 hanya mampu melayani 98,48 \% kebutuhan air bersih ( Tabel 3 dan Gambar 8)

c. Skenario terpadu (penghematan dan konservasi)

Berdasarkan Gambar 8 adanya kebijakan penghematan dan konservasi maka neraca air mengalami surplus. Neraca air skenario 3 pada tahun 2009 sebesar $22.800 .000 \mathrm{~m}^{3} /$ tahun dan pada tahun 2032 sebesar 2.023.137,08 $\mathrm{m}^{3} /$ tahun. Nilai indeks ketersediaan air (IKA) pada tahun 2009 sebesar 1573,44 dan terus menurun sehingga pada tahun 2032 nilai IKA 117,92 ini memunujukan bahwa pada tahun 2032 mampu melayani 117,92 \% kebutuhan air bersih (Gambar 9 dan Tabel 4).

Skenario 3 (skenario terpadu) menghasilkan neraca air yang surplus sampai akhir tahun simulasi, karena adanya upaya konservasi seperti reboisasi sebesar $10 \%$, pembuatan sumur resapan $1 \%$ dan terasering $1 \%$ dan penghematan penggunaan air sebesar $10 \%$.

Tabel 2 : Neraca air dan IKA eksisting

\begin{tabular}{|c|c|c|c|c|}
\hline Years & Kebutuhan air total eksisting & ketersediaan air tanah eksisting & Neraca air eksisting & IKA eksisting \\
\hline 2009 & 1.610 .058 .80 & 22.800 .000 .00 & 21.189 .941 .20 & 1.416 .10 \\
\hline 2010 & 1.638 .389 .65 & 20.520 .032 .47 & 18.881 .642 .82 & 1.252 .45 \\
\hline 2011 & 1.687 .300 .55 & 18.468 .089 .24 & 16.800 .788 .69 & 1.107 .88 \\
\hline 2012 & 1.696 .808 .45 & 16.621 .340 .34 & 14.924 .531 .89 & 979.56 \\
\hline 2013 & 1.726.931.17 & 14.959.286.33 & 13.232 .335 .18 & 886.23 \\
\hline 2014 & 1.757 .687 .43 & 13.483 .399 .72 & 11.705 .712 .29 & 765.97 \\
\hline 2015 & 1.789 .096 .98 & 12.117 .119 .77 & 10.328 .022 .79 & 677.28 \\
\hline 2016 & 1.821 .180 .81 & 10.905 .467 .82 & 9.084 .287 .21 & 598.81 \\
\hline 2017 & 1.853 .960 .29 & 9.814 .981 .08 & 7.961 .020 .77 & 529.41 \\
\hline 2018 & 1.887 .459 .22 & 8.833 .542 .98 & 6.946 .083 .75 & 488.01 \\
\hline 2019 & 1.921 .701 .96 & 7.950 .248 .70 & 6.028 .546 .74 & 413.71 \\
\hline 2020 & 1.956 .714 .52 & 7.155 .283 .85 & 5.198 .569 .33 & 385.68 \\
\hline 2021 & 1.992 .524 .47 & 6.439 .815 .49 & 4.447.291.02 & 323.20 \\
\hline 2022 & 2.029 .161 .10 & 5.795 .893 .97 & 3.708 .732 .87 & 285.63 \\
\hline 2023 & 2.088 .655 .52 & 5.216 .384 .59 & 3.149 .709 .07 & 252.41 \\
\hline 2024 & 2.105 .040 .84 & 4.694 .788 .16 & 2.589 .747 .31 & 223.03 \\
\hline 2025 & 2.144 .352 .34 & 4.225 .369 .38 & 2.081 .017 .03 & 197.05 \\
\hline 2028 & 2.184 .627 .61 & 3.802 .892 .45 & 1.618 .264 .84 & 174.08 \\
\hline 2027 & 2.225 .908 .80 & 3.422 .863 .23 & 1.198 .756 .43 & 153.78 \\
\hline 2028 & 2.288 .232 .80 & 3.080 .456 .93 & 812.224 .13 & 135.81 \\
\hline 2029 & 2.311 .651 .49 & 2.772 .471 .28 & 480.819 .77 & 119.93 \\
\hline 2030 & 2.356 .211 .99 & 2.495 .284 .16 & 139.072 .17 & 105.90 \\
\hline 2031 & 2.401 .986 .94 & 2.245 .815 .76 & -158.151 .18 & 93.50 \\
\hline Fina & 2.448 .972 .82 & 2.021 .294 .21 & -427.678 .61 & 82.54 \\
\hline$x i$ & $1 \square$ & & & 1 \\
\hline
\end{tabular}




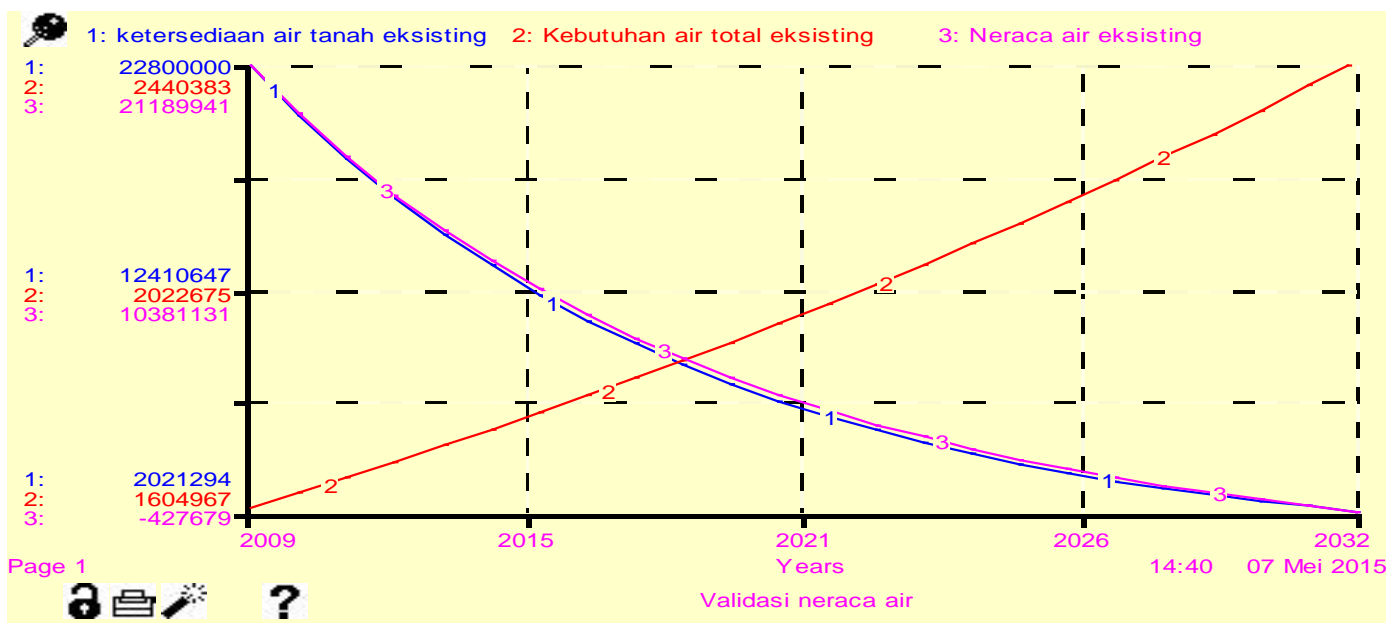

Gambar 5 : Validasi model neraca air

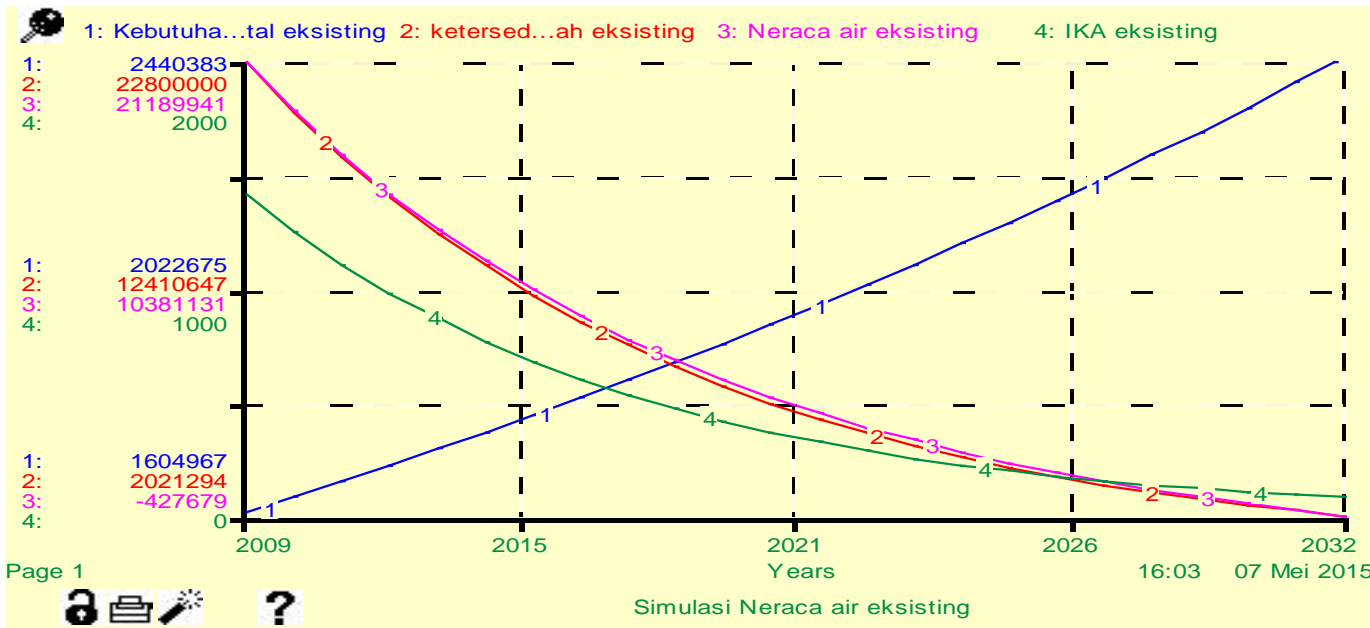

Gambar 6 : Simulasi neraca air eksisting

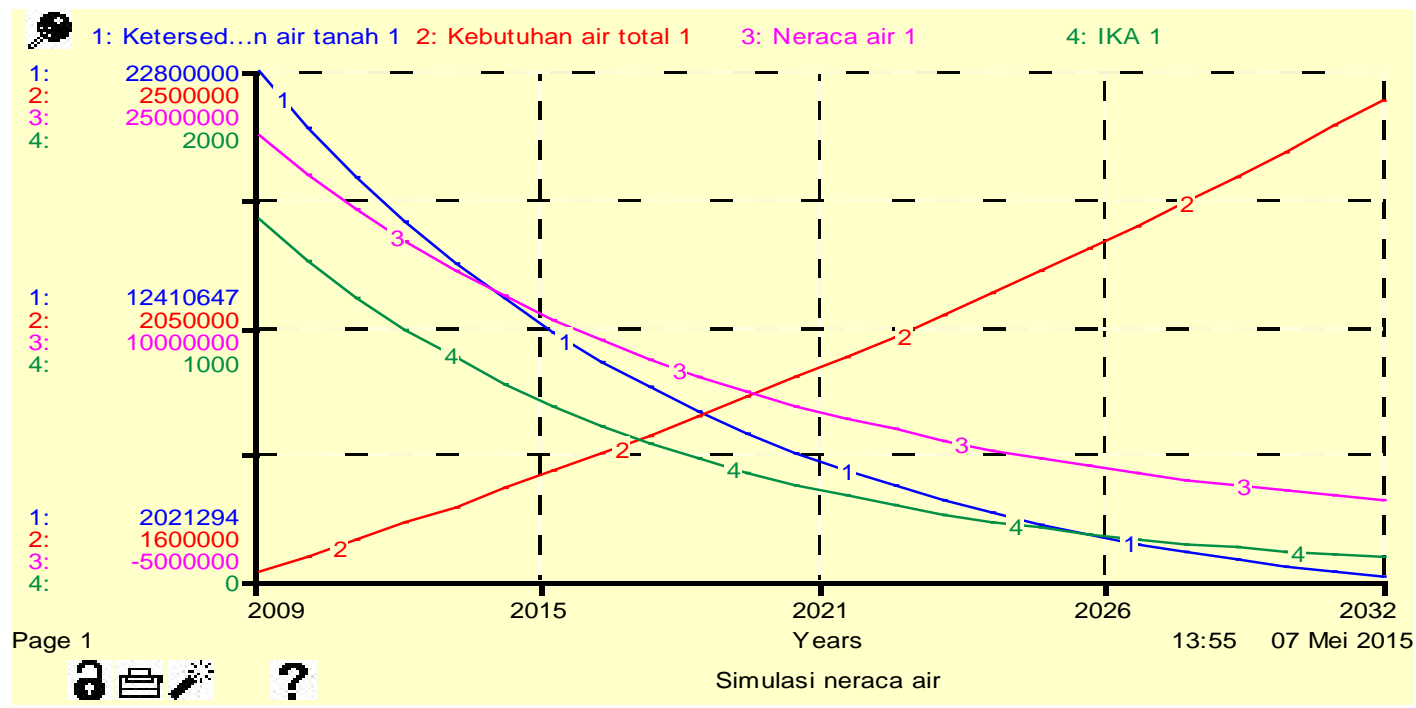

Gambar 7 : Simulasi skenario 1 (Bussines as usualy) 


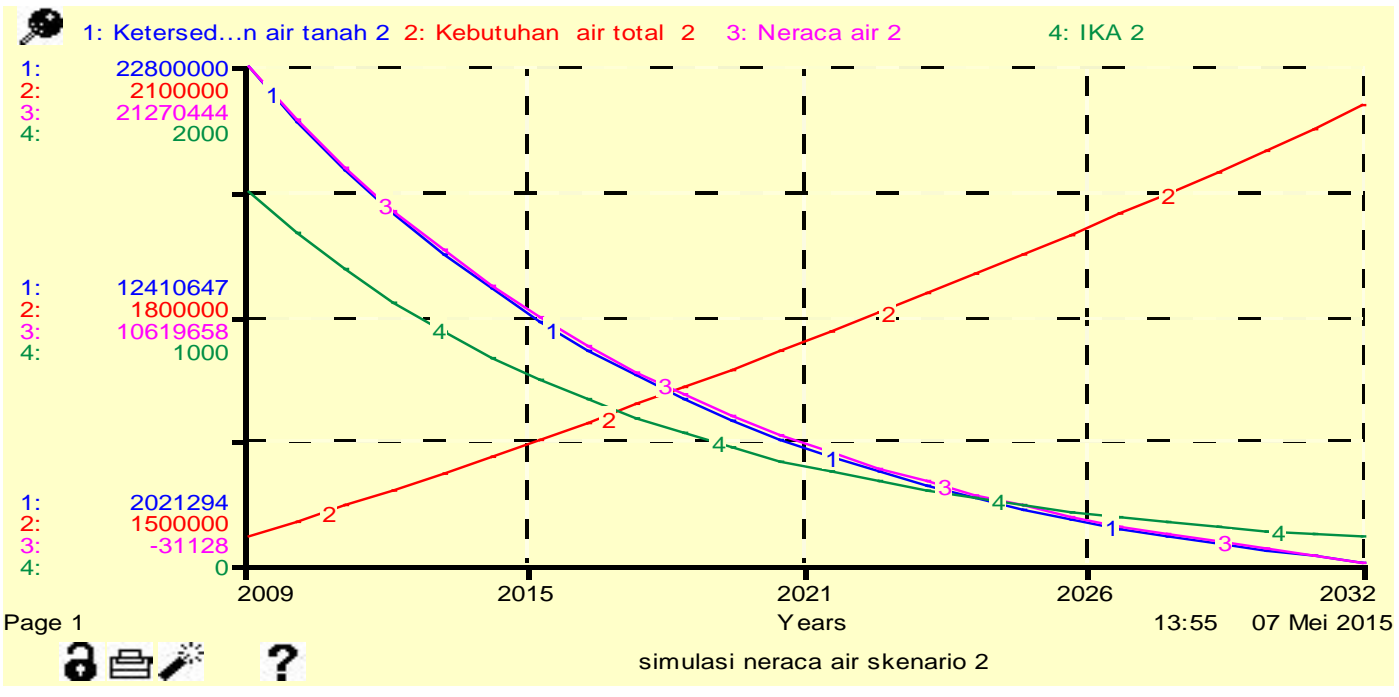

Gambar 8 : Simulasi Neraca air dan IKA skenario 2 (penghematan)

Tabel 3 : Ketersediaan air, kebutuhan air , neraca air dan IKA skenario 2

\begin{tabular}{|c|c|c|c|c|}
\hline Years & Ketersediaan air tanah 2 & Kebutuhan air total 2 & Neraca air 2 & IKA 2 \\
\hline 2009 & 22.800 .000 .00 & 1.529 .555 .86 & 21.270 .444 .14 & 1.490 .63 \\
\hline 2010 & 20.520 .032 .47 & 1.548 .590 .63 & 18.971 .441 .83 & 1.325 .08 \\
\hline 2011 & 18.468 .089 .24 & 1.567 .907 .82 & 16.900 .181 .42 & 1.177 .88 \\
\hline 2012 & 16.621 .340 .34 & 1.587 .513 .60 & 15.033 .826 .74 & 1.047 .00 \\
\hline 2013 & 14.959 .266 .33 & 1.607 .414 .36 & 13.351 .851 .97 & 930.64 \\
\hline 2014 & 13.463 .399 .72 & 1.627 .616 .76 & 11.835 .782 .96 & 827.18 \\
\hline 2015 & 12.117 .119 .77 & 1.648 .127 .74 & 10.468 .992 .03 & 735.21 \\
\hline 2016 & 10.905 .467 .82 & 1.668 .954 .49 & 9.236 .513 .33 & 653.43 \\
\hline 2017 & 9.814 .981 .06 & 1.690 .104 .53 & 8.124 .876 .53 & 580.73 \\
\hline 2018 & 8.833 .542 .98 & 1.711 .585 .68 & 7.121 .957 .29 & 516.10 \\
\hline 2019 & 7.950 .248 .70 & 1.733 .406 .13 & 6.216 .842 .58 & 458.65 \\
\hline 2020 & 7.155 .283 .85 & 1.755 .574 .38 & 5.399 .709 .48 & 407.58 \\
\hline 2021 & 6.439 .815 .49 & 1.778 .099 .35 & 4.661 .716 .14 & 362.17 \\
\hline 2022 & 5.795 .893 .97 & 1.800 .990 .34 & 3.994 .903 .62 & 321.82 \\
\hline 2023 & 5.216 .384 .59 & 1.824 .257 .10 & 3.392 .107 .50 & 285.94 \\
\hline 2024 & 4.694 .788 .16 & 1.847 .909 .80 & 2.846 .878 .35 & 254.06 \\
\hline 2025 & 4.225 .389 .36 & 1.871 .959 .13 & 2.353 .410 .23 & 225.72 \\
\hline 2028 & 3.802 .892 .45 & 1.896 .416 .28 & 1.906 .476 .17 & 200.53 \\
\hline 2027 & 3.422 .683 .23 & 1.921 .292 .96 & 1.501 .370 .27 & 178.14 \\
\hline 2028 & 3.080 .456 .93 & 1.946 .601 .49 & 1.133 .855 .44 & 158.25 \\
\hline 2029 & 2.772 .471 .26 & 1.972 .354 .80 & 800.116 .46 & 140.57 \\
\hline 2030 & 2.495 .284 .16 & 1.998 .568 .45 & 496.717 .70 & 124.85 \\
\hline 2031 & 2.245 .815 .76 & 2.025 .250 .74 & 220.565 .02 & 110.89 \\
\hline Final & 2.021 .294 .21 & 2.052.422.67 & -31.128 .46 & 98.48 \\
\hline
\end{tabular}




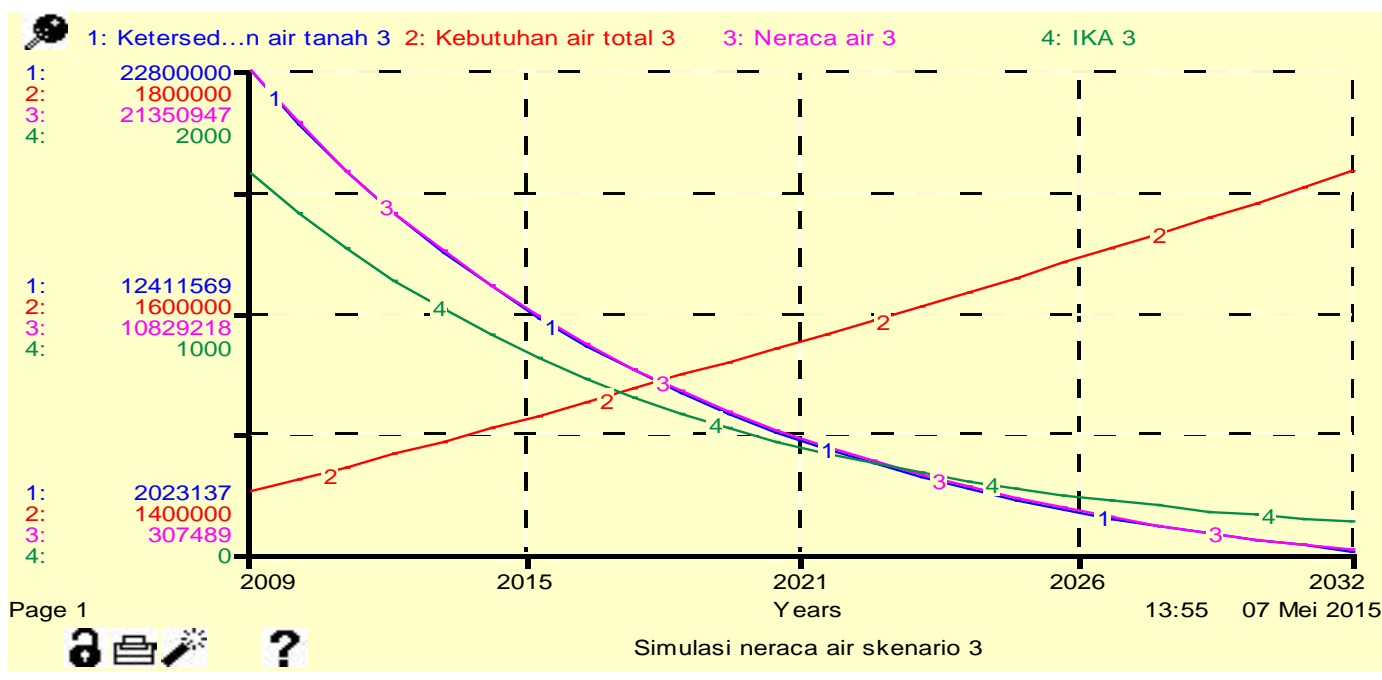

Gambar 9 : Neraca air dan IKA skenario 3

Tabel 4 : Ketersediaan air tanah, kebutuhan air, neraca air dan IKA skenario 3

\begin{tabular}{|c|c|c|c|c|}
\hline Years & Ketersediaan air tanah 3 & Kebutuhan air total 3 & Neraca air 3 & IKA 3 \\
\hline 2009 & 22.800 .000 .00 & 1.449 .052 .92 & 21.350 .947 .08 & 1.573 .44 \\
\hline 2010 & 20.520 .032 .47 & 1.459 .423 .76 & 19.060 .608 .70 & 1.406 .04 \\
\hline 2011 & 18.468 .293 .68 & 1.469 .892 .23 & 16.998 .401 .42 & 1.256 .44 \\
\hline 2012 & 16.621 .728 .73 & 1.480 .459 .93 & 15.141 .268 .81 & 1.122 .74 \\
\hline 2013 & 14.959 .820 .30 & 1.491 .128 .49 & 13.468 .691 .81 & 1.003 .25 \\
\hline 2014 & 13.464 .102 .71 & 1.501 .899 .61 & 11.962 .203 .10 & 896.47 \\
\hline 2015 & 12.117 .956 .88 & 1.512 .775 .06 & 10.605 .181 .82 & 801.04 \\
\hline 2016 & 10.906 .425 .63 & 1.523 .756 .64 & 9.382 .688 .99 & 715.76 \\
\hline 2017 & 9.816 .047 .51 & 1.534 .846 .23 & 8.281 .201 .28 & 639.55 \\
\hline 2018 & 8.834 .707 .20 & 1.546 .045 .76 & 7.288 .681 .44 & 571.44 \\
\hline 2019 & 7.951 .500 .92 & 1.557 .357 .25 & 6.394 .143 .67 & 510.58 \\
\hline 2020 & 7.156 .615 .27 & 1.588 .782 .75 & 5.587 .832 .51 & 456.19 \\
\hline 2021 & 6.441 .218 .18 & 1.580 .324 .43 & 4.860 .893 .75 & 407.59 \\
\hline 2022 & 5.797 .360 .80 & 1.591 .984 .51 & 4.205 .376 .29 & 364.16 \\
\hline 2023 & 5.217 .889 .16 & 1.603 .765 .28 & 3.614 .123 .89 & 325.35 \\
\hline 2024 & 4.696 .364 .68 & 1.615 .689 .13 & 3.080 .695 .56 & 290.68 \\
\hline 2025 & 4.226 .992 .68 & 1.627 .698 .53 & 2.599 .294 .12 & 259.69 \\
\hline 2026 & 3.804 .557 .83 & 1.639 .856 .08 & 2.164 .701 .77 & 232.01 \\
\hline 2027 & 3.424 .386 .49 & 1.652 .144 .37 & 1.772 .222 .11 & 207.27 \\
\hline 2028 & 3.082 .194 .28 & 1.664 .566 .22 & 1.417 .628 .05 & 185.17 \\
\hline 2029 & 2.774 .239 .29 & 1.677 .124 .48 & 1.097 .114 .81 & 165.42 \\
\hline 2030 & 2.497 .079 .80 & 1.689 .822 .12 & 807.257 .68 & 147.77 \\
\hline 2031 & 2.247 .636 .26 & 1.702 .682 .23 & 544.974 .03 & 132.01 \\
\hline Final & 2.023 .137 .08 & 1.715 .648 .02 & 307.489 .05 & 117.92 \\
\hline
\end{tabular}

\subsection{Pembahasan}

\subsubsection{NeracaAir di Pulau Tidore}

Siklus hidrologi, penjelasan mengenai hubungan antara aliran ke dalam (inflow) dan aliran keluar (outflow) di suatu daerah untuk suatu periode tertentu disebut neraca air (water balance ${ }^{6)}$. Neraca air (water balance) merupakan neraca masukan dan keluaran air disuatu tempat pada periode tertentu, sehingga dapat digunakan untuk mengetahui jumlah air tersebut kelebihan (surplus) ataupun kekurangan $(\text { defisit })^{7)}$. Kegunaan dari neraca air adalah untuk mengetahui kondisi air surplus dan defisit dapat mengantisipasi bencana yang kemungkinan terjadi, serta dapat pula untuk mendayagunakan air sebaikbaiknya. Manfaat neraca air secara umum antara lain: a. Sebagai dasar pembuatan bangunan penyimpanan dan pembagi air serta saluransalurannya. 
b. Sebagai dasar pembuatan saluran drainase dan teknik pengendalian banjir

c. Sebagai dasar pemanfaatan air alam untuk berbagai keperluan pertanian seperti sawah, perkebunan dan perikanan.

Neraca air merupakan metode yang sering digunakan untuk mengetahui kuantitas dan waktu ketersediaan air pada suatu unit wilayah. Data neraca air dapat memberikan beberapa keterangan penting tentang jumlah neto air yang dapat diperoleh, nilai surplus air yang tidak tertampung dan kapan saat terjadinya.

Berdasarkan hasil simulasi model neraca air di Pulau Tidore dari tahun 2009 sampai tahun 2032 menunjukan bahwa kondisi eksisting neraca air di pulau Tidore terjadi defisit sebesar 156.151,18 dan tahun 2032 sebesar 427.678,61 $\mathrm{m}^{3}$ /tahun pada tahun sedangkan pada tahun 2031 sampai tahun 2032 terjadi defisit. ketersediaan air tanah pada tahun 2031 berkurang menjadi 2.401.966,94 $\mathrm{m}^{3} /$ tahun dan tahun 2032 sebesar 2.448.972,82 $\mathrm{m}^{3} /$ tahun . Salah satu informasi yang dihasilkan dari analisis neraca air adalah informasi mengenai besaran dan waktu ketersediaan air yang melimpah atau surplus air yang tinggi. Neraca air ini memuat situasi ketersediaan dan kebutuhan air untuk berbagai penggunaan air. Neraca air antara lain dapat diperoleh dengan membuat super posisi antara ketersediaan air dengan kebutuhan air ${ }^{8)}$.

Defisit air dapat terjadi bila kandungan air tanah yang ada tidak cukup untuk memenuhi kebutuhan air potensialnya9). Untuk mengurangi terjadinya defisit air maka perlu diupayakan beberapa skenario kebijakan yakni penghematan penggunaan air (reduce dan reuse) dan konservasi air tanah. Dari ketiga skenario tersebut diatas skenario terpadu (penghematan dan konsevasi) dapat menaikan ketersediaan air tanah sehingga tidak terjadi defisit, berdasarkan hasil simulasi skenario terpadu maka dapat dilihat bahwa terjadi surplus ketersediaan air sampai tahun 2032.

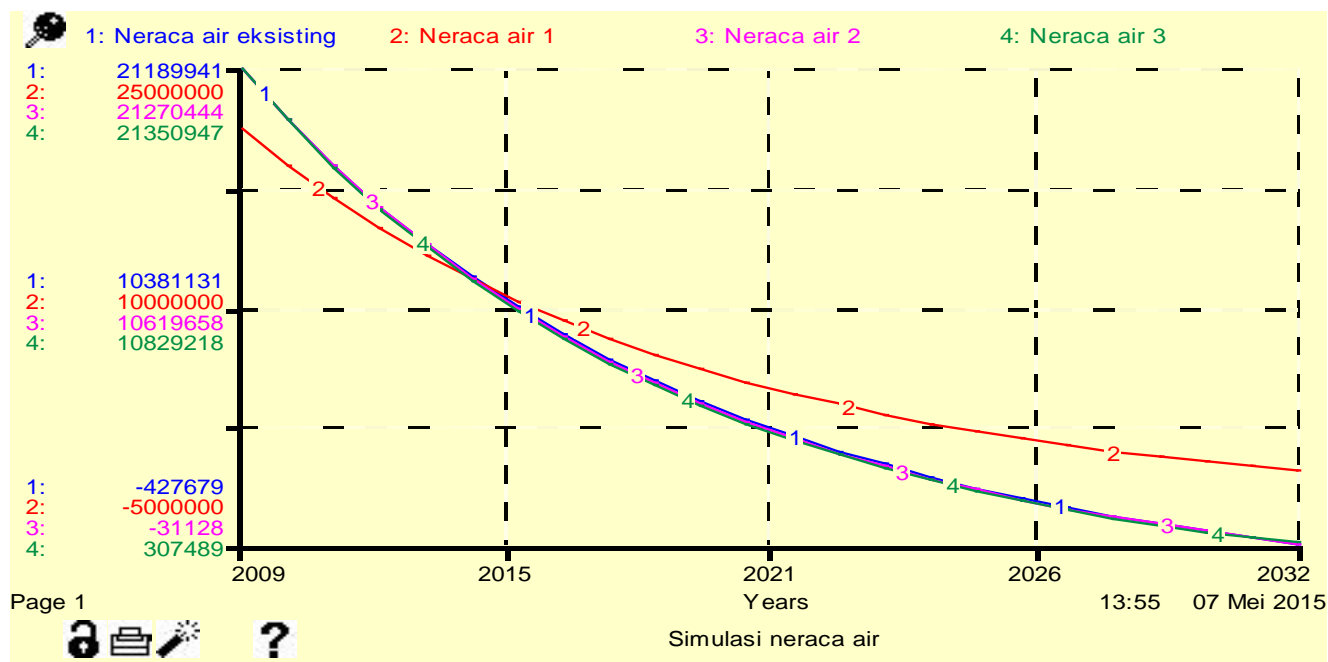

Gambar 10.Simulasi neraca air

\section{SIMPULAN DAN SARAN}

\subsection{Simpulan}

Berdasarkan hasil analisis sistem dinamik maka dapat disimpulkan :

a. Model neraca air di bangun dari dua sub model yakni sub model kebutuhan air dan sub model ketersediaan air tanah. Hasil simulasi setiap variabel menunjukan terjadi defisit ketersediaan air seiring dengan meningkatnya kebutuhan air.

b. Upaya kebijan hemat air dan konservasi pada masing land use meningkatkan neraca air.

\subsection{Saran}

Untuk meningkatkan perubahan kinerja model maka skenario yang yang perlu dilakukan adalah skenario terpadu dengan melakukan intervensi yang lebih besar dari kondisi eksisting pada masing-masing land use.

\section{DAFTAR PUSTAKA}

1. Sanim.B. 2011. Sumberdaya Air dan Kesejahteraan Publik. IPB Press, Bogor

2. Hartrisari. 2007. Sistem Dinamik : konsep Sistem dan Pemodelan Untuk industri Muhammadi, Aminullah E, Soesilo B.2001.

3. Barlas.Y 1996,Aspect of Model Validity and Validation in System Dynamics, System Dynamic Review, Vol. 12 No 3

4. Muhammadi, Aminullah E, Soesilo B. 2001 Analisis Sistem Dinamis . UMJ Press. Jakarta 
5. Badan Pusat Statistik Kota Tidore Kepulauan 2010 Kota Tidore Kepulauan dalam Angka tahun 2010

6. Muliya.H. 2013. Analisis Ketersediaan Air Pulaupulau Kecil di Daerah CAT dan Non CAT dengan Cara Perhitungan Metode Mock yang Dimodifikasi. Tekno Sipil Vol. 11 No 58

7. Purnama.I.L.S, Trijuni.S, Hanafi.F, Aulia.T, Razali.R.2012.Analisis Neraca air di DAS Kupang dan Singkarang. Percetakan Pohon Cahaya, Jogjakarta
8. Barmawi M, E. Mawardi dan W. Hatmoko. 2007. Penelitian Ketersediaan Air Irigasi di Kota Payakumbuh Dalam Rangka Peningkatan Produksi Padi. Jurnal Sumber daya Air.Vol. 3 No.4 : 41-48.

9. Djufry.F. 2012. Pemodelan Neraca Air Tanah untuk Pendugaan Surplus dan Defisit Air untuk Pertumbuhan Tanaman Pangan di Kabupaten Merauke Papua.Informatika Pertanian.Vol 21 No 1 : 1 
